\title{
DETERMINANTS OF THE PROFITABILITY OF BANKING SECTOR IN TURKEY
}

\author{
TÜRKIYYE'DE BANKACILIK SEKTÖR ̈UNÜN KARLILIĞININ \\ BELIRLEYICCILERI
}

Hakan BAL ${ }^{(1)}$, S1tkı SÖNMEZER ${ }^{(2)}$

\begin{abstract}
The profitability of banks is an important subject around the world, since the banking system is a vital component in any economy, thus interests many parties including investors and regulatory bodies. This study aims to shed light to the factors that affect the profitability of banks in Turkey across bank types using the annual data for the banks in Turkey between 2004 and 2017. Overall, credit riskiness, funding cost and GDP growth has a positive effect and operating cost has a negative effect on bank profitability. Higher illiquidity, funding cost and operating cost significantly positively affects profitability for large, private and foreign banks but not for state banks. Labor productivity however, while significantly positively affects profitability for foreign banks, it has a negative effect on profitability for large and private banks. The findings suggest important regulatory suggestions for the banking and finance system.
\end{abstract}

Keywords: Financial Markets, Banking, Profitability, Panel Data

Öz: Her ekonomi için bankacılık sistemi yaşamsal öneme sahip bir bileşen olduğundan, bankacılık kârı da küresel düzeyde öneme sahiptir ve yatırımcılar ile düzenleyici yapılar gibi bir çok tarafin ilgisini çekmektedir. Bu çalışmanın amacı, 2004 ve 2017 arasındaki Türkiye'deki bankaların yıllık raporlarını kullanarak Türk bankalarının karlılı̆̆ı üzerinde etkili unsurlara ışık tutmaktır. Genel olarak, kredi riski, fonlama maliyetleri ve gayrisafi yurtiçi hasıla büyümesinin tüm banka çeşitlerinin karlılı̆̆ında anlamlı pozitif, operasyon maliyetlerinin ise negatif etki ettiği görülmüş̧ür. Likidite düşüklüğ̈̈, fonlama maliyeti ve GSYH büyümesi özel ve yabancr bankalar için pozitif etkiye sahipken, operasyon maliyetinin etkisi negatif olarak bulunmuştur; bu durum devlet bankaları için geçerli değildir. Işsgücü üretkenliği ise yabancı bankaların karlılığını pozitif yönde etkilerken, büyük ve özel bankalar için negatif yönde etki bulunmuştur. Bulgular bankacılık ve finans sistemine ilişkin önemli politika önerileri ortaya koymuştur.

Anahtar Kelimeler: Finansal Pazarlar, Bankacılık Sektörü, Kârlılık, Panel Veri

JEL: G10, G21, G30, C23

\footnotetext{
(1) Beykent Üniversitesi, İ̈BF Fakültesi, Uluslararası Ticaret Bölümü; hakanbal@beykent.com.tr, ORCID: 0000-0001-8477-5150

(2) İstanbul Ticaret Üniversitesi, İİBF Fakültesi, Finans ve Bankacılık Bölümü; ssonmezer@ticaret.com.tr, ORCID: 0000-0002-9704-2199

Geliş/Received: 09-12-2021; Kabul/Accepted: 05-01-2022
} 


\section{Introduction}

Profitability of the Turkish banking sector have attracted foreign investors' attention and funds for the recent decades. Currently, Spanish bank BBVA has offered $15 \%$ premium to increase her share from $80 \%$ to obtain the rest of the shares as of November 2021. By intuition, this offer should be made for the possible future profits that are expected to increase once the pandemic is over.

The profitability of banks is of interest by investors, depositor and of course regulators. There are numerous country specific and cross-country studies examining the determinants of profitability of the banks. Using bank level data from 80 countries, a cross-country study found that in countries with low bank assets to GDP and higher interest rates profitability is higher, while lower leverage, lower loans-to-assets ratio, lower non-interest earning assets, and foreign ownership increases it (Demirgüç-Kunt and Huizinga, 1999:396-398). Using a GMM framework, another study found that lower leverage, lower credit provisions, higher labor productivity, lower other expenses (wage etc.) and GDP growth increases profitability for Greek banks (Athanasoglou, Brissimis and Delis, 2008:127).

This study categorizes Turkish banks into groups of; state, foreign and private banks and aims to put forth the determinants of the profitability overall and also for each type of bank. For each type of bank, profitability and constraints may differ, leading to different profitability determinants.

Measuring profitability as return on assets, it is found that higher loan-to-asset ratio, interest paid to depositors and GDP growth has a positive effect and operating expenses ratio has a negative effect on bank profitability. On the other hand, higher loan to asset ratio, interest paid to depositors and operating expenses ratio significantly positively affects profitability for large, private and foreign banks but not for state banks. Revenue per employee however, while significantly positively affects profitability for foreign banks, it has a negative effect on profitability for large and private banks.

The paper is organized as follows. Section 2 reviews Turkish banking sector and section 3 provides a literature survey on the subject. Data and methodology are discussed in section 4. Results are then discussed in section 5 and section 6 concludes.

\section{A Brief Review of Turkish Banking Sector}

As of 2021, there are 55 banks in the Turkish banking system and three major ones are state owned. 34 of them are deposit banks. 6 of them are participation banks and 15 of them are development and investment banks. 21 banks in the banking system have foreign participation. 184,694 people (61,419 in state owned banks) are employed in 9,863 branches at the deposit banks and development and investment banks which indicates a $1.1 \%$ decrease compared to the previous year (The Banks Association of Turkey, 2021).

Asset size of the Turkish banking sector is 7,046,833 million TL; 4,038,148 million TL of credits and securities of Turkish banks profitability varies for state owned banks and private banks significantly. Credit Guarantee Fund (CGF) was founded to support the economy during COVID 19 crisis. Majority of the loans are sold by three state owned banks at very competitive prices. Mortgages are similarly sold at much lower rates compared to private banks. For January 2020, net interest income of state-owned banks has decreased by $69 \%$ resulting in a fall of net income from 2.3 billion TL to 6 
million TL whereas net interest income of the overall income has decreased only by $20 \%$ (Fitch Ratings, 2021).

\section{Related Theories and Literature}

The determinants of profitability, investigated of 42 Indian banks, were found to be provisions for non-performing assets to loans, capital to asset ratio, annual growth of deposits, non-interest income and operating expenses to total assets. GDP growth and inflation rate are also incorporated into their model as macroeconomic variables and Herfindahl-Hirschman Index (HHI) (positive) is also used to capture the industry specific effects (Sinha and Sharma, 2016: 38-39). Another study has applied a twostep Generalized Method of Moments (GMM) to 18 Pakistan banks for the sample period of 2007-2016. Size, higher solvency, financial structure, operating costs, labor productivity, market power and economic growth are found to have significant positive effect on banks profitability. Whereas, credit quality, operational efficiency, banking sector development, inflation and concentration in the industry are found to have significant impact on banks profitability (Yao, Haris and Tariq, 2018: 6-7). Using data of 23 countries from 2002 to 2016 and dynamic GMM analysis, a study finds that overhead costs decrease profitability while the number of automated teller machines and the number of point of sale terminals improves bank profitability (Le and Ngo, 2020: 6). Another study focuses on 47 Asian countries between 1995 and 2017, and using GMM framework it finds while loan loss provisions, nonperforming loans have a negative effect on profitability, capital adequacy, illiquidity (loan-toassets) and GDP growth have a positive effect (Saif-Alyousfi, 2020: 10). Using VECM methodology for the state bank data from Indonesia between 2007 and 2017, another study finds operating costs, loan-to-deposit ratio, non-performing loans and economic growth is positively associated with bank profitability (Prasanto, Wulandari, Narmaditya, and Kamaludin, 2020: 35). Using bank data from Turkey between 1960 and 2015 and employing ARDL methodology, another study finds positive effect of capital adequacy, liquidity, inefficiency and inflation and negative effects of credit risk and oil prices on long run bank profitability (Katırcioglu, Ozatac, and Taspinar, 2020: 577). Another study on Morocco banks between 1997 and 2018 finds positive effects of size, liquidity, interbank rate and inflation and negative effect of loan-to-deposits and banking sector size on bank profitability (Derbali, 2021: 110).

Regarding the Turkish banking sector, some studies have provided evidence via a panel data analysis that production index, off balance sheet activities, non-performing loans and personnel expenses to total revenues ratio have positive effects on ROA of the Turkish banking sector for the years 1995 to 2009 (Taskin, 2011: 293-294); and some have stated that capital adequacy contributes to banking profitability (Okuyan and Karatas, 2017: 395). Capital size, credit portfolio size and extent of ownership concentration are found to be significant determinants of bank profitability in Nigeria, deposit liabilities, labor productivity and the relationship between bank risk and profitability is inconclusive (Aburime, 2008: 67-68).

In this study we measure the effects of loss provisions to total loans (credit riskiness), loans to assets ratio (illiquidity), equity-to-assets ratio (solvency), interest payments to deposits ratio (funding cost), operating expenses (other) to total assets ratio (operating cost), interest income to total employees (labor productivity) and gross 
domestic product (GDP) growth on bank profitability measured with return to assets (net income to assets).

Return on assets: This variable is computed as net income to total assets ratio, as in previous studies (Athanasoglou et.al., 2008:127; Dietrich and Wanzenried, 2011: 311).

Credit riskiness: The effect of loan loss provisions divided by total loans ratio measures the riskiness of the bank loans (Dietrich and Wanzenried, 2011: 311). Higher provisions imply the loans given by the bank are riskier.

Illiquidity: A higher loans to assets ratio means more of bank assets are loaned out, resulting in lower liquidity and higher risk for the bank (Gul, Irshad and Zaman, 2011: 69). On the other hand, a higher ratio also means the bank is using its assets more efficiently as loans, so improving liquidity.

Solvency: Lower values of equity to assets ratio imply higher leverage and risk for the bank. Banks with better solvency, arguably face lower borrowing costs which improves their profitability (Demirgüç-Kunt and Huizinga, 1999: 396-398; Naceur and Goaied, 2001: 319; Dietrich and Wanzenried, 2011: 313). So, solvency should be positively related to profitability.

Funding cost: Interest payments to deposits divided by average deposits ratio measures the cost of deposits for the bank (Dietrich and Wanzenried, 2011: 313). The banks which have low funding costs are expected to perform better.

Operating cost: This is measured by the ratio of operating expenses (other) which includes amortization and wage expenses divided by average assets (Athanasoglou, Brissimis and Delis, 2008: 127). The banks which have low operating costs are expected to perform better.

Labor productivity: The productivity of labor can be computed by dividing interest income by average number of employees where the averages are computed by the average values at the beginning and end of the fiscal year (Athanasoglou, Brissimis and Delis, 2008: 127). The banks which have high labor productivity are expected to perform better.

GDP growth: GDP growth is expected to have a positive effect on bank profitability, as evidenced by the positive correlation between the GDP growth and banking sector development (Demirgüç-Kunt and Huizinga, 1999: 396-398; Dietrich and Wanzenried, 2011: 313). The data on GDP growth was collected from World Bank data in current USD terms.

\section{Data and Methodology}

The dataset comprises of the annual data of 36 deposit banks between 2004 and 2017, which is gathered from the Banks Association of Turkey website. Seven banks with less than 3 years of data have been dropped. Table 1 shows the periods and lists of the banks included in the study, which include 3 state banks, 12 private banks and 14 foreign banks. 7 of them have halted their operations before the end of the sample due to takeovers, mergers and acquisitions, but included to avoid possible survivorship bias.

Table 2 shows the summary statistics. Return on assets is highest in state owned banks and lowest in private banks having an average of $1.5 \%$, close to previous studies 
(Taskın, 2011: 295). Credit riskiness, loan provisions to loans, is almost same around $11 \%$ significantly lower than $16.3 \%$ found in another study on Turkish banks between 1995 and 2009 (Taskın, 2011: 295). Liquidity, inverse of loans to assets, is higher for state banks, which means less of their assets are used in loans. State banks have lower solvency, equity to assets, and show much less variability than foreign or private banks. The average figure is close to 12.7 found in another study between 1995 and 2009 (Taskın, 2011: 295). Funding costs are around $7 \%$ for all banks. Operating costs (other) of private and foreign banks almost double the operating costs of state banks, $4 \%$ and $2 \%$ respectively. Labor productivity is highest for state banks, while for private banks labor productivity is lowest.

Table 1: Composition of the banks in the sample

\begin{tabular}{|c|c|c|c|c|c|c|c|}
\hline Type & Name & Start & End & Type & Name & Start & End \\
\hline State & $\begin{array}{l}\text { Türkiye } \\
\text { Cumhuriyeti } \\
\text { Ziraat Bankası }\end{array}$ & 2004 & 2017 & Foreign & Alternatifbank & 2004 & 2017 \\
\hline State & $\begin{array}{l}\text { Türkiye Halk } \\
\text { Bankası }\end{array}$ & 2004 & 2017 & Foreign & $\begin{array}{l}\text { Arap Türk } \\
\text { Bankası }\end{array}$ & 2004 & 2017 \\
\hline State & $\begin{array}{l}\text { Türkiye Vakıflar } \\
\text { Bankası }\end{array}$ & 2004 & 2017 & Foreign & Burgan Bank & 2013 & 2017 \\
\hline Private & Akbank & 2004 & 2017 & Foreign & Citibank & 2004 & 2017 \\
\hline Private & Anadolubank & 2004 & 2017 & Foreign & Denizbank & 2004 & 2017 \\
\hline Private & Fibabanka & 2012 & 2017 & Foreign & Deutsche Bank & 2007 & 2009 \\
\hline Private & Fortis Bank & 2006 & 2010 & Foreign & $\begin{array}{l}\text { Eurobank } \\
\text { Tekfen }\end{array}$ & 2008 & 2011 \\
\hline Private & Oyak Bank & 2004 & 2007 & Foreign & Finans Bank & 2004 & 2017 \\
\hline Private & Tekstil Bankası & 2004 & 2014 & Foreign & HSBC Bank & 2004 & 2017 \\
\hline Private & Turkish Bank & 2004 & 2017 & Foreign & ING Bank & 2009 & 2017 \\
\hline Private & Turkland Bank & 2007 & 2017 & Foreign & $\begin{array}{l}\text { Millennium } \\
\text { Bank }\end{array}$ & 2007 & 2010 \\
\hline Private & $\begin{array}{l}\text { Türk Ekonomi } \\
\text { Bankası }\end{array}$ & 2004 & 2017 & Foreign & Odea Bank & 2013 & 2017 \\
\hline Private & $\begin{array}{l}\text { Türkiye İş } \\
\text { Bankası }\end{array}$ & 2004 & 2017 & Foreign & Tekfenbank & 2004 & 2006 \\
\hline Private & $\begin{array}{l}\text { Yapı ve Kredi } \\
\text { Bankası }\end{array}$ & 2004 & 2017 & Foreign & $\begin{array}{l}\text { Türkiye } \\
\text { Garanti } \\
\text { Bankası }\end{array}$ & 2004 & 2017 \\
\hline Private & Şekerbank & 2004 & 2017 & & & & \\
\hline
\end{tabular}

The model we employed is fixed effects regression. The fixed effects model is stated in Equation 1 for bank $i$ and year $t$. Heteroscedasticity tests are performed and standard errors are adjusted by clustering within banks as needed. For the state banks, since the number of clusters is small (only three), fixed effects with autocorrelated errors are used, which adds the condition that $u_{i t}$ are autocorrelated with lag one in Equation 1. For the same reason, a random effects test is not performed, and test against OLS is done using an F-test listed in the Table 3. 


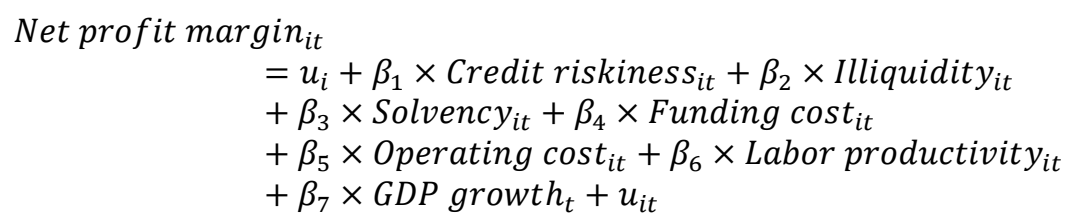

Out of the set of exogenous variables, six are bank dependent; credit riskiness, illiquidity, solvency, funding cost, operating cost and labor productivity; bank independent variable is GDP growth. The dependent variable of profitability, return on assets (ROA), is defined by net income divided by average total assets. Credit riskiness is defined by loan loss provisions divided by total loans, illiquidity is defined by loans divided by assets, solvency defined by equity divided by assets, funding cost is interest payments to deposits divided by average deposits, operating cost is defined by operating expenses (other) which includes amortization and wage expenses divided by average assets, labor productivity is defined by interest income divided by average number of employees.

Table 2: Summary statistics

\begin{tabular}{lccccc}
\hline & All & Largest 10 & State & Private & Foreign \\
\hline Return on & 1.49 & 1.85 & 2.10 & 1.24 & 1.54 \\
assets (\%) & $(1.35)$ & $(1.41)$ & $(0.64)$ & $(1.47)$ & $(1.34)$ \\
& & & & & \\
Credit & 0.10 & 0.10 & 0.11 & 0.10 & 0.11 \\
riskiness & $(0.26)$ & $(0.25)$ & $(0.25)$ & $(0.25)$ & $(0.27)$ \\
Illiquidity & 0.56 & 0.56 & 0.50 & 0.58 & 0.56 \\
& $(0.15)$ & $(0.12)$ & $(0.17)$ & $(0.14)$ & $(0.15)$ \\
& & & & & \\
Solvency & 0.12 & 0.11 & 0.10 & 0.13 & 0.13 \\
& $(0.05)$ & $(0.02)$ & $(0.01)$ & $(0.03)$ & $(0.06)$ \\
Funding cost & 0.07 & 0.07 & 0.08 & 0.07 & 0.06 \\
& $(0.03)$ & $(0.02)$ & $(0.03)$ & $(0.02)$ & $(0.02)$ \\
$\begin{array}{l}\text { Operating } \\
\text { cost }\end{array}$ & 0.04 & 0.03 & 0.02 & 0.04 & 0.04 \\
& $(0.02)$ & $(0.01)$ & $(0.00)$ & $(0.02)$ & $(0.02)$ \\
$\begin{array}{l}\text { Labor } \\
\text { productivity }\end{array}$ & $(0.39)$ & $(0.34)$ & $(0.40)$ & $(0.26)$ & $(0.46)$ \\
\hline $\begin{array}{l}\text { Observations } \\
\text { No of banks }\end{array}$ & 308 & 140 & 42 & 135 & 131 \\
\hline
\end{tabular}

mean coefficients; standard deviations in parentheses

\section{Findings}

Table 3 provides evidence for the determinants of profitability for Turkish banks. The model fits the largest banks better than state and private banks (R-squared of $62 \%$, $19 \%$ and $46 \%$ respectively), while for foreign banks the fit is poor (R-squared of $3.9 \%$ ). This implies the profitability of smaller banks and foreign banks may rely on 
other factors than the determinants under study, while for large banks and private banks they play a more significant role.

For all banks and largest 10 banks; credit riskiness (t-value of 4.44 and 6.31), illiquidity (t-value of 2.42 and 2.31), funding cost (t-value of 2.92 and 2.78), operating cost (t-value of -1.95 and -5.25) and GDP growth (t-value of 4.11 and 6.29) have statistically significant effect on banks' net profit margin. Credit riskiness, illiquidity and funding cost increases profitability, while operating costs decrease it. GDP growth has a positive impact on profitability.

Credit riskiness has a higher effect on profitability for private banks and foreign banks than state banks (coefficients of 2.19 and 2.48 vs 1.43 respectively). For largest ten banks the effect is even stronger (a coefficient of 2.76). The relation has been examined widely but mixed results are reached in the literature. Some studies find non-performing loans have a significant negative effect on profitability internationally and for Turkish banks (Kadioglu, Telceken and Ocal, 2017:65; Sahyouni and Wang, 2018:77; Sinha and Sharma, 2016:42; Athanasoglou et.al., 2008:133; Ozgur and Gorus, 2016: 227; Katırcioglu, Ozatac and Taspınar, 2020: 576), some studies find a positive effect for net interest margin (Le and Ngo, 2020: 6), while other studies find no significant effects (Aburime, 2008:31; Taskın, 2011:296; Dietrich and Wanzenried, 2011:319) on profitability. Issuing loans with higher credit risk seem to be more profitable during this period.

Illiquidity has a significant positive effect on profitability for private and foreign banks but not for state banks (t-values of 2.00 and 2.02 vs 0.11 respectively). Aburime (2008:31) finds no significant effect while Gul et.al. (2011:79) and Taskın (2011:296) find positive effect on bank profitability. Abreu and Mendes (2003:8) also find positive relation for the banks in Portugal, Spain, France and Germany. Banks loaning out more of their assets seem to be more profitable during this period.

Solvency has no effect on profitability for all groups of banks. Some studies find a positive effect on profitability using Turkish bank data, Sri Lanka bank data and Greek bank data (Ozgur and Gorus, 2016: 227; Ayadi and Boujelbene, 2012: 14; Athanasoglou et.al., 2008:133). Also, a positive relationship is found for the banks in 11 developed and emerging economies (Sahyouni and Wang, 2018:77). On the other hand, a negative relation is found for Swiss banks (Dietrich and Wanzenried, 2011: 319).

Our findings show that funding cost has a significant positive effect on profitability for private and foreign banks but not for state banks (t-values of 2.52, 2.49 and 0.90 respectively). This stands in contrast with previous results that funding cost has a significant negative effect on bank profitability for emerging economies but not for developed economies (Sahyouni and Wang, 2018:77). A negative effect of funding costs is found for the profitability of banks in Switzerland (Dietrich and Wanzenried, 2011: 319). The funding cost is highly correlated with interest rates especially for state banks ( 0.94 vs 0.79 and 0.54 for private and foreign banks respectively with 10 year Turkish bond yield), which was not included in this study due to multicollinearity. Other studies find a positive effect of interest rates on bank profitability (DemirgüçKunt and Huizinga, 1999:396-398; Athanasoglou et.al. 2008: 133). Demirgüç-Kunt and Huizinga (1999: 405) argue that developing country demand deposits typically pay zero or below market rates. Arguably, higher interest rates may increase loan rates 
and profitability but not affect deposit rates, leading to a positive coefficient for funding cost.

Operating cost has a significant negative effect on profitability for largest banks and private banks ( $\mathrm{t}$-values of -5.25 and -3.06 respectively), while effects in state and foreign banks are insignificant ( $\mathrm{t}$-values of 0.24 and -0.74 respectively). A positive effect of operating expenses is found on profitability for Indian banks (Sinha and Sharma, 2016: 38-39), while a negative effect is found for Greek banks (Athanasoglou et.al. 2008: 133).

Table 3: Determinants of profitability in Turkish banking sector

\begin{tabular}{|c|c|c|c|c|c|}
\hline $\begin{array}{l}\text { Dependent: } \\
\text { Return on assets (\%) }\end{array}$ & $\begin{array}{l}\text { (1) } \\
\text { All }\end{array}$ & $\begin{array}{c}(2) \\
\text { Largest } 10\end{array}$ & $\begin{array}{c}(3) \\
\text { State }\end{array}$ & $\begin{array}{c}\text { (4) } \\
\text { Private }\end{array}$ & $\begin{array}{c}(5) \\
\text { Foreign }\end{array}$ \\
\hline Credit riskiness & $\begin{array}{l}2.54^{* * *} \\
(4.44)\end{array}$ & $\begin{array}{c}2.76^{* * *} \\
(6.31)\end{array}$ & $\begin{array}{l}1.43^{* * *} \\
(3.15)\end{array}$ & $\begin{array}{l}2.19^{* * *} \\
(4.04)\end{array}$ & $\begin{array}{l}2.48^{* * * *} \\
(4.33)\end{array}$ \\
\hline Illiquidity & $\begin{array}{l}3.58^{* *} \\
(2.42)\end{array}$ & $\begin{array}{l}3.51^{* *} \\
(2.31)\end{array}$ & $\begin{array}{c}0.17 \\
(0.11)\end{array}$ & $\begin{array}{l}2.59^{*} \\
(2.00)\end{array}$ & $\begin{array}{l}4.23^{*} \\
(2.02)\end{array}$ \\
\hline Solvency & $\begin{array}{c}3.92 \\
(0.90)\end{array}$ & $\begin{array}{c}2.44 \\
(0.35)\end{array}$ & $\begin{array}{c}4.58 \\
(0.81)\end{array}$ & $\begin{array}{l}4.85 \\
(1.11)\end{array}$ & $\begin{array}{l}-6.70 \\
(-1.71)\end{array}$ \\
\hline Funding cost & $\begin{array}{c}13.97^{* * *} \\
(2.92)\end{array}$ & $\begin{array}{l}14.43^{* *} \\
(2.78)\end{array}$ & $\begin{array}{c}4.57 \\
(0.90)\end{array}$ & $\begin{array}{l}15.70^{* *} \\
(2.52)\end{array}$ & $\begin{array}{l}9.98^{* *} \\
(2.49)\end{array}$ \\
\hline Operating cost & $\begin{array}{l}-64.65^{*} \\
(-1.95)\end{array}$ & $\begin{array}{c}-112.9^{* * *} \\
(-5.25)\end{array}$ & $\begin{array}{l}10.01 \\
(0.24)\end{array}$ & $\begin{array}{c}-100.4^{* *} \\
(-3.06)\end{array}$ & $\begin{array}{l}-6.38 \\
(-0.74)\end{array}$ \\
\hline Labor productivity & $\begin{array}{c}-0.21 \\
(-0.59)\end{array}$ & $\begin{array}{l}-0.86^{*} \\
(-1.90)\end{array}$ & $\begin{array}{c}-0.01 \\
(-0.05)\end{array}$ & $\begin{array}{l}-1.61^{*} \\
(-2.13)\end{array}$ & $\begin{array}{l}0.68^{* *} \\
(2.25)\end{array}$ \\
\hline GDP growth & $\begin{array}{l}7.03^{* * *} \\
(4.11)\end{array}$ & $\begin{array}{l}7.26^{* * * *} \\
(6.29)\end{array}$ & $\begin{array}{l}2.71^{* *} \\
(2.45)\end{array}$ & $\begin{array}{l}5.94^{* * *} \\
(4.97)\end{array}$ & $\begin{array}{l}6.06^{* * *} \\
(4.10)\end{array}$ \\
\hline Observations & 308 & 140 & 39 & 135 & 131 \\
\hline No of groups & 29 & 10 & 3 & 12 & 14 \\
\hline F-value & $5.34^{* * *}$ & $81.7^{* * * *}$ & $2.58^{* * *}$ & $22.8^{* * *}$ & $9.42^{* * *}$ \\
\hline Overall $\mathrm{R}^{2}$ & 0.059 & 0.62 & 0.19 & 0.46 & 0.039 \\
\hline SH test & $22.36^{* * *}$ & $10.68^{*}$ & - & $281.7^{* * *}$ & $49.52^{* * *}$ \\
\hline BPLM test & $115.4^{* * *}$ & $40.90^{* * *}$ & - & $67.84^{* * *}$ & $17.75^{* * *}$ \\
\hline Heterosce. & $3525^{* * *}$ & $255.2^{* *}$ & $15.1^{* * *}$ & $497.2^{* * *}$ & $184.2^{* * *}$ \\
\hline $\begin{array}{l}\text { F-test for panel } \\
\text { effects (df1,df2) }\end{array}$ & $\begin{array}{c}9.58^{* * *} \\
(28,272)\end{array}$ & $\begin{array}{l}6.01^{* * *} \\
(9,123)\end{array}$ & $\begin{array}{l}2.65^{*} \\
(2,29)\end{array}$ & $\begin{array}{c}7.74^{* * *} \\
(11,116) \\
\end{array}$ & $\begin{array}{c}9.90^{* * *} \\
(13,110)\end{array}$ \\
\hline
\end{tabular}

t-ratios are in parentheses. ${ }^{*} \mathrm{p}<0.05,{ }^{* *} \mathrm{p}<0.01,{ }^{* * *} \mathrm{p}<0.001$. SH test refers to Sargan-Hansen FE/RE test, BPLM Breusch and Pagan Lagrange multiplier test for RE specification, Heteroscedasticity test is Modified Wald test computed from the FE specification.

Labor productivity has a significant negative effect for largest banks (t-value of -1.90) and private banks (t-value of -2.13) and positive effect for foreign banks (t-value of 2.25). A study found no effect for Turkish banks (Taskin, 2011: 296). Other studies found positive effect for Tunisian banks and for Greek banks (Naceur and Goaied, 2001: 318; Athanasoglou et.al., 2008: 133). Arguably, within foreign banks, hiring more efficient workers leads to higher profitability, but for state and private banks the hiring process seem to be more uniform across the banks. Combined with the results 
for operating cost, largest banks and private banks have seem to be less efficient in managing their operating expenses, particularly wage expenses.

The effect of GDP growth is significant for all banks but larger for large banks, private banks and foreign banks (a coefficient of 7.26, 5.94 and 6.06 respectively) than state banks (a coefficient of 2.71). Demirgüç-Kunt and Huizinga (1999:396-398) find GDP growth and solvency positively affects bank profitability, short term funding and noninterest bearing assets have negative impact. Thus, state bank profits seem to be affected least by business cycles. This may be due to the composition of the portfolios of the banks; private and foreign banks may be financing private sector more, while state banks may finance public sector, leading to an asymmetric effect of business cycles on bank profitability.

\subsection{Robustness checks}

The dataset is divided into two panels based on years, pre and post 2010. The results are shown in the first and second column of Table 4. The common determinant in both periods and the complete period in first column of Table 3 is GDP growth. The determinants across the years have significantly changed across years. Before 2010, credit risk has a significant positive effect while it has a negative effect post-2010. Solvency, which is insignificant in the complete dataset (first column of Table 3), is significant post-2010. These findings suggest that there may be a structural break for the determinants of profitability between 2004 and 2017.

Since the dataset is unbalanced, a balanced panel is ran using the data of the banks which have no missing data throughout the years. The results are displayed third column of Table 4. The number of banks drops from 29 to 17, however now the panel is strictly balanced. The signs, significance and even the size of the coefficients are not affected significantly compared to the first column of Table 3, where the data is unbalanced. Solvency however becomes significant at $10 \%$ significance (t-value of 1.86 in balanced data vs 0.90 in the unbalanced data). So, solvency may be a significant factor of profitability for the banks which survived throughout the sample period.

The fourth column in Table 4 shows the results using year dummies. The significance of credit riskiness and funding cost drops when year dummies are included. Upon close inspection, the funding cost is in a steady decline across years for most banks, so the findings about the funding cost may due to omitted macro variables also declining in time. Other macroeconomic variables may be included alongside using cross country data in future studies to alleviate this problem. Other macroeconomic variables are not included in this study due to high multicollinearity.

\section{Conclusion}

The determinants of bank profitability have been the subject of many studies, both in developed economies and emerging economies. In this study we find that credit riskiness, funding cost and GDP growth has a positive effect and operating cost has a negative effect on bank profitability. The positive effect of funding cost credit riskiness may be an artifact of omitted variable bias, particularly a macro variable in our study, since they become insignificant after including time fixed effects.

We also examine the determinants of bank profitability across different bank types; state, private and foreign. Credit riskiness (loan loss provisions to loans ratio) and 
GDP growth have significantly positive effects on profitability across all types of banks. Higher illiquidity (loans to assets ratio) significantly positively affects profitability for large, private and foreign banks but not for state banks. Similarly, funding cost (interest paid to deposits to deposits ratio) significantly positively affect profitability, while operating cost (other operating expenses to assets) have significant negative affect on profitability, for large, private and foreign banks but not for state banks. Labor productivity however, while significantly positively affects profitability for foreign banks, it has a negative effect on profitability for large and private banks.

Table 4: Robustness checks

\begin{tabular}{lcccc}
\hline & $(1)$ & $(2)$ & $(3)$ & $(4)$ \\
Dependent: & All & All & All & $\begin{array}{c}\text { All } \\
\text { (pre-2010) }\end{array}$ \\
Return on assets (\%) & post-2010) & $\begin{array}{c}\text { (Balanced panel) } \\
\text { (Year dummies) }\end{array}$ \\
\hline Credit riskiness & $1.39^{*}$ & $-14.84^{* * *}$ & $2.52^{* * * *}$ & 1.54 \\
& $(1.86)$ & $(-3.23)$ & $(4.95)$ & $(0.38)$ \\
Illiquidity & 1.02 & 1.24 & $4.32^{* *}$ & $5.80^{* * * *}$ \\
& $(0.58)$ & $(1.27)$ & $(2.71)$ & $(3.32)$ \\
Solvency & 0.67 & $13.81^{* * *}$ & $8.43^{*}$ & 4.19 \\
& $(0.17)$ & $(3.98)$ & $(1.86)$ & $(1.05)$ \\
Funding cost & 7.19 & 2.44 & $17.88^{* * *}$ & -1.28 \\
& $(1.59)$ & $(0.40)$ & $(3.43)$ & $(-0.17)$ \\
Operating cost & $-83.62^{* *}$ & -11.83 & $-69.20^{* *}$ & $-85.91^{* * *}$ \\
& $(-2.26)$ & $(-0.79)$ & $(-2.07)$ & $(-2.85)$ \\
Labor productivity & 0.59 & 0.30 & -0.41 & 0.34 \\
& $(0.83)$ & $(1.28)$ & $(-0.96)$ & $(1.34)$ \\
GDP growth & $4.69^{* *}$ & $2.43^{* * *}$ & $7.06^{* * * *}$ & \\
& $(2.29)$ & $(3.39)$ & $(4.42)$ & \\
Year dummy & No & No & No & Yes \\
\hline Observations & 154 & 154 & 238 & 308 \\
No of groups & 26 & 24 & 17 & 29 \\
F-value & 1.71 & 12.9 & 6.22 & 11.9 \\
Overall R & 0.084 & 0.14 & 0.23 & 0.085 \\
SH test & $56.08^{* * *}$ & $21.77^{* * *}$ & $15.37^{* *}$ & $529.59^{* * * *}$ \\
BPLM test & $45.85^{* * *}$ & $99.95^{* * *}$ & $76.56^{* * *}$ & $142.70^{* * *}$ \\
Heterosce. & $37653.02^{* * * *}$ & $4986.51^{* * *}$ & $1065.28^{* * * *}$ & $11448.39^{* * *}$ \\
F-test for panel & $7.99^{* * *}$ & $12.12^{* * *}$ & $7.73^{* * *}$ & $13.49^{* * * *}$ \\
effects (df1,df2) & $(25,121)$ & $(23,123)$ & $(16,214)$ & $(28,260)$ \\
\hline
\end{tabular}

t-ratios are in parentheses. ${ }^{*} \mathrm{p}<0.05,{ }^{* *} \mathrm{p}<0.01,{ }^{* * *} \mathrm{p}<0.001$. SH test refers to Sargan-Hansen FE/RE test, BPLM Breusch and Pagan Lagrange multiplier test for RE specification, Heteroscedasticity test is Modified Wald test computed from the FE specification. Year dummies refers to the specification with dummy variables added for each year.

Our results indicate the determinants of profitability change across bank types, particularly between state and non-state banks. Some of our results, particularly about credit riskiness and funding cost may suffer from the omitted variable bias, particularly due to an omitted macro variable. Since funding costs decline across years under study, simply including other time variables pose a collinearity problem. In future studies, using a sample with longer time horizon, additional macro variables or a cross-country analysis may be useful. 
Our results from the robustness checks suggest the determinants of profitability change across time. The determinants before 2010 are rather different from the determinants after 2010 for Turkey. There may be structural breaks about the determinants of bank profitability in the time horizon considered here, which is crucial for policy making and investment decisions. More research on this subject is needed, particularly involving structural breaks. Also, the results with year dummies suggest there may be other macroeconomic variables that affect the bank profitability, not included in this study due to high multicollinearity. Cross country studies such as Demirgüç-Kunt and Huizinga (1999), Abreu and Mendes (2003) and Sahyouni and Wang (2018) may be more resilient to this phenomenon, however there may be cross country differences in the determinants of bank profitability. GDP growth is the consistent factor of bank profitability throughout the data sample and across bank types, especially for large banks, private banks and foreign banks, implying that their profitability to be cyclical. So, during downturns, these banks may be more prone to facing difficulties, which may be a concern for their investors and regulators.

\section{References}

Aburime, T. (2008). Determinants of bank profitability: Company-level evidence from Nigeria. Available at SSRN 1106825.

Abreu, M., \& Mendes, V. (2003). Do macro-financial variables matter for European bank interest margins and profitability?. Paper presented at EcoMod Network Conference, Istanbul.

Athanasoglou, P. P., Brissimis, S. N., Delis, M. D. (2008). Bank-specific, industryspecific and macroeconomic determinants of bank profitability. Journal of International Financial Markets, Institutions and Money, 18(2), 121-136.

Ayadi, N., and Boujelbene, Y. (2012). The determinants of the profitability of the Tunisian deposit banks. IBIMA Business Review, 2012, 1-21. doi: $10.5171 / 2012.165418$

Demirgüç-Kunt, A., and Huizinga, H. (1999). Determinants of commercial bank interest margins and profitability: some international evidence. The World Bank Economic Review, 13(2), 379-408.

Derbali, A. (2021). Determinants of the performance of Moroccan banks. Journal of Business and Socio-economic Development, 1(1), 102-117.

Dietrich, A., and Wanzenried, G. (2011). Determinants of bank profitability before and during the crisis: Evidence from Switzerland. Journal of International Financial Markets, Institutions and Money, 21(3), 307-327.

Fitch Ratings. (2021). Turkish banks' profits face added pressure from rate rise. Access address: https://www.fitchratings.com/research/banks/turkishbanks-profits-face-added-pressure-from-rate-rise-19-03-2021

Gul, S., Irshad, F., \& Zaman, K. (2011). Factors affecting bank profitability in Pakistan. Romanian Economic Journal, 14(39), 61-87.

Hirindu, K., and Panditharathna, K. (2017). The factors effecting on bank profitability. International Journal of Scientific and Research Publications, 7(2), 212-216.

Kadioglu, E., Telceken, N., Ocal, N. (2017). Effect of the asset quality on the bank profitability. International Journal of Economics and Finance, 9(7), 60-68. 
Katırcioglu, S., Ozatac, N., \& Taspınar, N. (2020). The role of oil prices, growth and inflation in bank profitability. The Service Industries Journal, 40(7-8), 565584.

Le, T. D., \& Ngo, T. (2020). The determinants of bank profitability: A cross-country analysis. Central Bank Review, 20(2), 65-73.

Naceur, S. B., and Goaied, M. (2001). The determinants of the Tunisian deposit banks' performance. Applied Financial Economics, 11(3), 317-319.

Okuyan, H. A. and Karataş, Y. (2017). Türk Bankacılık Sektörünün Kârlılık Analizi (Profitability Analysis of Turkish Banking Sector). Ege Academic Review, 17(3), 395-406.

Ozgur, O., and Gorus, M. S. (2016). Determinants of deposit bank profitability: evidence from Turkey. Journal of Applied Economics and Business Research, 6(3), 218-231.

Prasanto, O., Wulandari, D., Narmaditya, B. S., \& Kamaludin, M. (2020). Determinants of bank profitability: A new evidence from state-owned banks in Indonesia. Trikonomika, 19(1), 29-35.

Sahyouni, A., and Wang, M. (2018). The determinants of bank profitability: does liquidity creation matter?. Journal of Economics and Financial Analysis, 2(2), 61-85.

Saif-Alyousfi, A. Y. (2020). Determinants of bank profitability: evidence from 47 Asian countries. Journal of Economic Studies, 49(1), 44-60.

Sinha, P., and Sharma, S. (2016). Determinants of bank profits and its persistence in Indian Banks: a study in a dynamic panel data framework. International Journal of System Assurance Engineering and Management, 7(1), 35-46.

Taskın, F. D. (2011). Türkiye'de ticari bankaların performansını etkileyen faktörler. Ege Akademik Bakış, 11(2), 289-298.

The Banks Association of Turkey. (2021). Bankacılık Sisteminde Banka, Çalışan ve Şube Sayıları. Access address: https://www.tbb.org.tr/Content/Upload/istatistikiraporlar/ekler/3681/Banka_Calisan_ve_Sube_Bilgileri_Eylul_202 1.pdf

Yao, H., Haris, M., and Tariq, G. (2018). Profitability determinants of financial institutions: evidence from banks in Pakistan. International Journal of Financial Studies, 6(2), 53 